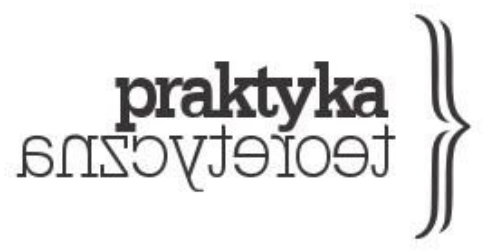

ISSN 2081-8130

DOI: $10.14746 /$ prt.2015.2.9 www.praktykateoretyczna.pl

\title{
CRISIS OF LAW OF VALUE AND THE REAL SUBSUMPTION OF LABOR UNDER CAPITAL. QUESTIONS FOR MICHAEL HARDT
}

\author{
KRYSTIAN SZADKOWSKI
}

In the last issue of "Historical Materialism", the journal board decided to reprint a text by Tony Smith discussing the ideas of Paolo Virno (2007) and Carlo Vercellone (2007) on the general intellect (Smith 2013). It is a part of the wider critical attack on the post-operaist reading of Marxian "Fragment on Machines" carried out under the leadership of Italian economist Ricardo Bellofiore in his co-edited book In Marx's Laboratory. The general idea behind the texts included in the volume is to put in question the whole strategy of reading Grundrisse against Capital (with a particular focus on the project that could be dated back to Antonio Negri's Marx oltre Marx) (Bellofiore 2013).

The philological arguments against the post-operaist projects are more or less simple and well known. For example, Caffentzis' (2005) accusations against the post-operaist use of the concept of real subsumption refer first of all to the idea that Marx treated the concept of real subsumption of labor under capital as being fully realized during his time in the large scale industry. Moreover, neither in Capital nor in the Economic Manuscripts of 1861-1863 or in Results of Immediate Process of Production (the unpublished $6^{\text {th }}$ chapter of 1864) did he use the concept of subsumption under capital in a different way than suggesting that it is a form of subordination of certain labor in a particular sector or region of production. The wider argument that refers to the formulation of the thesis of the crisis of the law of value states that Grundrisse is far less 
developed than Capital, and Marx himself dropped out (at the threshold of 1864) the idea of finishing the sixth book project of The Critique of Political Economy and turned his work completely toward Capital. One cannot assert, the argument goes, the validity of the thesis on the crisis of the law of value on the basis of the "Fragment on machines" (and Negri's (1989: 142-143) thesis on the real subsumption of society under capital could be traced back to these passages). The reason is that the very Marxian theory of value (despite the formulation of the theory of surplus value), with its fundamental binary pairs like concrete and abstract labor or absolute and relative value, was still unwritten at the level of Grundrisse. Michael Heinrich (2013) claims that for this reason Marx was supposed to stop his argument at the level of extrapolation of his (very common at that time) empirical observations without going further into the realm of theory. The lack of the categories of concrete and abstract labor allows Marx to assume that when the direct labor process is becoming an inferior source of material wealth, its time stops being the measure of wealth creation. According to Heinrich, the value of every commodity, even an immaterial one, could be assessed and is assessed by reference of the amount of abstract labor it contains to the socially necessary labor time. And for example, the process of establishing the socially necessary labor time for certain branches of immaterial production through the information gathered from the market of competing firms was proved to be possible by Massimo de Angelis (2005) in his very classically looking schemas. Moreover we could find countless examples of establishing well-functioning, subtle and practical mechanisms of measures based on the direct labor time in the sphere of biopolitical production, from DeskTime or ProTime applications to different forms of quantitative measures in the academic publishing industry (rankings, impact factors etc.).

However for people like George Caffentzis (2005) the political problem with the thesis on crisis of law of value, on which the hypothesis of real subsumption is based, is even more disturbing. Caffentzis claims that Marx's discourse on value plays at least three important functions, without which he could not imagine real revolutionary theory and politics. First of all, it has a deep analytical meaning. According to Caffentzis, from the time of its formulation the mentioned law was and still is a tool used to precisely define and describe the relations of exploitation in capitalist society. Second, it simultaneously performs a critical function: the law of value not only puts workers at the center of production process, but also determines their key role in the development of capital. Thirdly, the revolutionary feature of Marx's law of value is visible in its force to fuel the projects of building alternatives to the capitalist order. Deprived of this law, we are trapped in a class struggle stuck at the horizon of a Hegelian "bad infinity" which is always present, which always makes a step forward, but which never constitutes this next step.

It is obvious, that a science (even if it is an armed instrument of working class struggle) that is unable to forget its founders is already doomed, and such a process of constructive 
forgetting could be found in Negri's attempt to go beyond Marx. My question here is rather simple. If the thesis on the crisis of the law of value is at the core of the further project of the common, as well as the foundation of the thesis on the real subsumption of society under capital (and, as we have seen in Commonwealth (Hardt, Negri 2009: 313-315), it is transplanted without major reformulation from the works of the early 1990's) how could we defend it against all above mentioned accusations? Even the very interesting idea from the sphere of geographies of production, about the move backwards (and forward) between formal and real subsumption, discussed in other contributions, seems to be rather superficial and unimportant in the whole project of the common. In Commonwealth we can find many efforts to equip the theory of the common with analytical (theory of biopolitical exploitation), critical, and revolutionary (e.g. institutions of the common) features. There are also various texts by Negri where he calls for the development of common-theory of value or a theory of value based on the common. We have read pages of multifarious ideas heading into this direction, with the greatest example of the Tableau Economique of the common from Commonwealth. However, unfortunately, they still seem to be in their very incipient stage. Could you elaborate on the meaning of such projects in your use of the thesis on the crisis of the law of value and the thesis on the real subsumption of society under capital?

The second problem that I would like to raise for the seminar discussion starts with the claim by Ricardo Bellofiore and Massimiliano Tomba (2013) that your reading of the hegemonic position of biopolitical labor or Vercellone's thesis on the shift towards cognitive capitalism, seems to be highly problematic. The main reason is that looking through this schema of contemporary global production we remain blind to the mutual entanglement of various forms of extraction of surplus value that are irreducible to any linear sequence or the sum of clearly separated counterparts. Although there are many blind spots in the proposition of Bellofiore and Tomba, I think that they touched on the heart of the problem of the most standard post-operaist reading of the concept of subsumption, where like in Vercellone's approach (2007), the modes of subsumption seem to have the features of homogenous historical epochs, or like in Negri's interpretations (2003), they form a pervasive global mode of production. Even when there are efforts to break with the linear conceptualization of subsumption, we could find another failure in grasping how the increase in production of relative surplus value (based on the application of science and technology in the production process, aimed at shortening the time of necessary labor in relation with surplus labor time) through competition between capitals on a global scale, results in an increase in the production of absolute surplus value (based on the extension of the working day and the intensification of labor) (Tomba 2009). This level of analysis is essential for the move beyond a topological opposition of the center and periphery and a developmental understanding of the dynamics of capitalism declared by post-operaists. The increase of production based on a high rate of fixed 
capital results in, on the one hand, the exclusion of the labor force in West, and the conversion of masses into precarious and low-paid labor, on the other hand, in the enormous transfers of surplus value from the areas with low-wage, low share of fixed capital and high absolute exploitation to the capitalist center. This approach to the problem, in accordance with Marx's theory, assumes that the new production sectors are created in order to counteract the falling rate of profit and to maintain the production of relative surplus value. It is worth noting that such a reading allows us to conceptualize, through the lenses of one process either the recent penetration and development by capital of the sectors of immaterial production in Western countries, or the spread of poorly mechanized sewing in Bangladesh, both as a form of escape from the sectors dominated by organized labor and the high share of fixed capital involved in the production process. However such a view completely ignores the mutual development of such firms like Apple and Foxconn.

The Chinese "global superfactory", constituted by the network of Foxconn's production facilities, as time goes by, and the production expands, increases the mass of fixed capital in the form of machines and factories. The biggest global players on the electronic markets order at Foxconn more than a half of globally produced electronics nowadays. The Chinese enterprise employs around 1.23 million production workers, which means it is the tenth largest world employer and the first largest among private entities. However as Foxconn's operational margin decreases year after year (alongside the continuous, stable increase of its general income), at the same time, its biggest client, Apple, registers bigger and bigger profits.

As noted in the research report done by Pun Ngai (Pun et. al 2013), Foxconn's operational margin decreased from $3.7 \%$ in the first quarter of 2007 to $0.9 \%$ in the first quarter of 2012, with a general income of 114.72 billion dollars and an operational profit of 2,75 billion dollars in 2011. When we compare this data to Apple's financial results for the same period we can see clearly the growing evident domination of the sector of immaterial production over its industrial counterpart. At the moment Apple is one of the biggest firm noted on the global stock exchange market, with an increase in its operational margin in the analogical period from the $18.7 \%$ in the first quarter of 2007 to $39 . \%$ in the first quarter of 2012 . Its general income in 2013 was 170.91 billion dollars and its operational profit was around 48.9\% billion dollars.

However, despite the claims of critics like Tomba or Bellofiore, in the example of relation between Foxconn and Apple we can clearly see the hegemonic role of immaterial production and its evident domination over the industrial labor. It is obvious that the labor performed inside Foxconn factories is clearly under the real subsumption to capital (in the classical Marxian sense of the term), with the high level of use of the machinery and high level of investments in fixed capital, while labor inside the Apple enterprise is rather formally subsumed. So it is not a relationship that could be explained in a simple topological way (centers/peripheries - real subsumption/formal subsumption). 
Moreover, when we read the report by Pun Ngai, we can point out that even in the great example of industrial factories like those belonging to Foxconn, a vast number of techniques of labor discipline are used that are well known from the immaterial sectors of economy (of course there is also clear and direct military regime exercised over workforce in and outside the workplace, incomparable with anything we know from the sectors of biopolitical production in a more direct sense). First of all, there is the fact that more than $10 \%$ of the Foxconn labor force is recruited among university students through the system of low or unpaid internships that have nothing to do with their fields of professional expertise.

But how are we to conceptualize the mutual relationships of these two large firms in the categories of subsumption? Without Apple, Foxconn, a factory without a brand, can't produce and sell anything, or vica versa. Apple is at the same time an immaterial productive capital and a merchant capital, that despite employing its own productive biopolitical labor (formally subsumed) has to operate in a very close relation with the industrial capital of Foxconn, which employs low-waged and precarious migrant labor (however under real subsumption) through the means of state power and intervention (which suggest the form of hybrid subsumption in the Marxist sense). Or maybe the very concepts of formal, hybrid and real subsumption of labor under capital in their sector-of-production-oriented understanding are of no use anymore? 


\section{References}

Bellofiore, Ricardo. 2013. "The Grundrisse after Capital, or How to Re-read Marx Backwards". Trans. Peter. D. Thomas. In In Marx's Laboratory. Critical Interpretations of the Grundrisse. Eds. Ricardo Bellofiore, Giudo Starosta, Peter D. Thomas, Brill: Leiden.

Bellofiore, Ricardo and Massimiliano Tomba. 2013. The "Fragment on Machines" and the Grundrisse. The Workerist Reading in Question, Trans. Sara R. Farris, Peter D. Thomas. In Beyond Marx. Theorising the Global Labour Relations of the Twenty-First Century. Eds. Marcel van der Linden, Karl H. Roth. Brill: Leiden.

Caffentzis, George. 2005. Immesurable Value? An Essay on Marx's Legacy, The Commoner 10: 87-114.

De Angelis, Massimo. 2005. Value(s), Measure(s) and Disciplinary Markets, The Commoner 10: 66-86.

Hardt, Michael and Antonio Negri. 2009. Commonwealth. Belknap Press: New York.

Heinrich, Michael. 2013. The 'Fragment on Machines': A Marxian Misconception in the Grundrisse and its Overcoming in Capital. In In Marx's Laboratory. Critical Interpretations of the Grundrisse. Eds. Ricardo Bellofiore, Giudo Starosta, Peter D. Thomas, Brill: Leiden.

Negri, Antonio. 1989. Marx beyond Marx. Lessons on the Grundrisse. Trans. Harry Cleaver et. al. Autonomedia: New York.

Negri, Antonio. 2003. Time for Revolution. Trans. Matteo Mandarini, Continuum: London.

Pun, Ngai et. al. 2013. iSlaves - Ausbeutung und Widerstand in Chinas Foxconn-Fabriken, see. http://www.gongchao.org/de/islaves-buch

Smith, Tony. 2013. The 'General Intellect' in the Grundrisse and Beyond, Historical Materialism 21(4): 235-255.

Tomba, Massimiliano. 2009. Historical Temporalities of Capital: An Anti-Historicist Perspective. Historical Materialism 17(4): $44-65$.

Vercellone, Carlo. 2007. From Formal Subsumption to General Intellect: Elements for a Marxist Reading of the Thesis of Cognitive Capitalism. Trans. Peter D. Thomas, Historical Materialism 15(1): 13-36.

Virno, Paolo. 2004. The Grammar of the multitude. For an analysis of contemporary forms of life. Trans. Isabella Bertoletti, James Cascaito, Andrea Casson. Semiotext(e): Los Angeles.

Virno, Paolo. 2007. General Intellect. Trans. Adrianna Bové. Historical Materialism 15(3): 4-9. 
Krystian Szadkowski - is an assistant professor at the Institute of Philosophy and a researcher at the UNESCO Chair for Institutional Research and Higher Education Policy of Adam Mickiewicz University in Poznań, Poland. His research interests cover Marxian political economy, autonomist Marxism and transformation of higher education systems in Europe. Recently, he co-edited a collected volume Joy Forever: The Political Economy of Social Creativity (2014) and authored Uniwersytet jako dobro wspólne. Podstawy krytycznych badań nad szkolnictwem wy:̧şym (2015).

\section{ADDRESS:}

UNESCO Chair in Institutional Research and Higher Education Policy

ul. Szamarzewskiego 89

60-568 Poznań, Poland

EMAIL: krysszad@amu.edu.pl

CITATION: Szadkowski. Krystian. 2015. "Crisis of Law of Value and the Real Subsumption of Labor under Capital. Questions for Michael Hardt.” Praktyka Teoretyczna 2(16): 160-166.

DOI: $10.14746 /$ prt.2015.2.9

AUTOR: Krystian Szadkowski

TYTUL: Kryzys prawa wartości oraz realna subsumcja pracy pod kapitał. Pytania do Michaela Hardta. 